\title{
留 \\ ISLAM, POLIGAMI DAN PERLINDUNGAN KAUM PEREMPUAN
}

\author{
Agus Hermanto \\ IAIN Raden Intan Lampung \\ gusher.sulthani@gmail.com
}

\begin{abstract}
Abstrak
Berdasarkan fakta sejarah, praktek poligami sebenarnya sudah dilakukan oleh umat sebelum datangnya agama Islam. Ketika Islam datang, aturan tentang poligami muncul dalam rangka menyempurnakan syari'ah sebelumnya sekaligus untuk mengatur, membatasi dan memberikan suatu solusi bagi kebutuhan biologis manusia. Meski Islam memberi peluang bagi kaum pria untuk berpoligami, namun peluang tersebut sangat terbatas dan hanya dapat diberikan jika seseorang mampu berbuat adil dalam arti yang sebenar-benarnya. Oleh karena keadilan bukanlah sesuatu hal yang mudah untuk dilakukan, dapat disimpulkan bahwa meski Islam membolehkan poligami tetapi kecenderungan utamanya adalah monogami.
\end{abstract}

\begin{abstract}
Historically, the practices of polygamy has actually been done by the people before the advent of Islam. When Islam came, the rules on polygamy appears in order to enhance the previous Shari'ah (religious law) as well as to regulate, to restrict and to provide a solution for the human biological needs. Although Islam gives opportunities for men to practice polygamy, but these opportunities are very limited and can only be given if someone is able to do justice in the true sense. Since justice is not an easy thing to do, it can be concluded that although Islam allows polygamy but its main tendency is monogamous.
\end{abstract}

Kata Kunci: Poligami, Toleransi, Hak-hak Perempuan. 


\section{A. Pendahuluan}

Dehumanisasi (al-laa insaniyyah) terhadap kaum perempuan pernah terjadi dalam panggung sejarah. Bahkan hingga sekarang, kondisi tersebut masih dapat kita saksikan, betapa perdagangan perempuan, kekerasan dan pelecehan seksual seakan tidak pernah terlewatkan dalam berita-berita kriminal, baik melalui media masa maupun melalui media elektronik.

Islam membeikan perlindungan kepada perempuan dengan cara memberikan hak-haknya sebagaimana diberikannya kepada laki-laki dan menghapus diskiminasi antara perempuan dan lakilaki dalam memenuhi hak-haknya karena derajat perempuan sama dengan derajat laki-laki disisi Allah swt., kecuali hal-hal yang bersifat fungsi utama sesuai dengan kondrat masing-masing, itulah yang berbeda, tapi perbedaan itu tidaklah dijadikan sebagai hal yang bertentangan, bakhan itu saling melengkapi dan saling tolong menolong. ${ }^{1}$

Islam telah memberikan toleransi dalam hal perlindungan terhadap kaum peremuan, namun diskriminasi dan anggapan bahwa kaum perempuan sebagai kelas dua (second class), sehingga belum ada kesetaraan. Hal ini disebabkan oleh beberapa faktor; Pertama, budaya patriarkhi yang sedemikian lama mendominasi dalam masyarakat. Kedua, faktor politik, yang belum sepenuhnya berpihak kepada kaum perempuan. Ketiga, faktor ekonomi dimasa sistem kapitalisme global yang melanda dunia, sering kali justru mengekploitasi kaum perempuan. Keempat, faktor intepretasi teksteks agama, yang selama ini ditafsirkan secara patriarkhi. ${ }^{2}$

Salah satu masalah fikih munakahat yang banyak didiskusikan di masyarakat kita adalah poligami. Poligami adalah masalah yang sangat pelik yang dihadapi kaum perempuan dan Islam. bahkan, kalangan pengamat luar Islam (islamisis) menganggap dibolehkannya poligami ini membuktikan bahwa Islam sangat mengabaikan konsep demokrasi dan hak-hak asasi manusi

${ }^{1}$ Huzaimah Tahido Yanggo, Fikih Perempuan Kontemporer, (Bogor: Ghalia Indonesia, 2010), h. 139.

${ }^{2}$ Abdul Mustaqim, Paradigma Tafsir Feminis, (Yogyakarta: Logung Pustaka, 2008), h. 13. 
(perempuan) tanpa toleransi, dan ini dianggap sebagai sebuah diskriminasi terhadap kaum perempuan (isteri). ${ }^{3}$

\section{B. Pengertian}

Kata poligami terdiri dati kata poli artinya banyak dan gami isteri. ${ }^{4}$ Poligami berasal dari bahasa Yunani, polos, polus ${ }^{5}$ atau polys yang berarti banyak dan gamein atau gamos, yang berarti kawin. Jadi poligini artinya adalah kawin banyak, atau suami beristri banyak atau istri bersuami banyak pada saat yang sama. ${ }^{6}$ Atau dalam saat bersamaan seorang laki-laki kawin dengan lebih satu istri. Istilah poligami berarti pada saat/waktu bersamaan seorang laki-laki dengan banyak wanita atau wanita dengan banyak laki-laki. ${ }^{7}$

Poligami juga dapat diartikan perkawinan antara seorang dengan dua orang atau lebih (namun cenderung diartikan: perkawinan satu orang suami dengan dua orang isteri atau lebih). ${ }^{8}$ Secara terminologi, poligami terbagi menjadi dua, yakni poligini dan poliandri. Dalam bahasa Arab, poligami disebut ta'did zaujah (bilangan pasangan), dalam Islam poligami hanya dibatasi kepada empat isteri. Dalam bahasa Indonesia disebut permaduan dan dalam bahasa Sunda disebut Nyandung. ${ }^{9}$

Para ahli membedakan istilah bagi seorang laki-laki yang mempunyai lebih dari seorang isteri dalam istilah poligini. Poligini untuk suami yang beristeri banyak, berasal dari bahasa Yunani polys atau polus banyak dan gyne atau gune berarti istri (perempuan). Poligini dapat berarti bahwa seorang laki-laki dalam waktu yang sama berkawin dengan seorang wanita, tetapi dapat

${ }^{3}$ Syafiq Hasyim, Hal-Hal yang Tak Terpikirkan tentang Isu-Isu Keperempuanan dalam Islām, (Bandung: IKAPI, 2001), h. 159.

${ }^{4}$ Abdul Rahman Ghazali, Fikh Munakahat, (Jakarta: Kencana, 2003), h. 129.

${ }^{5}$ MA. Tihami dan Sohari Sahrani, Fikih Munakahat, (Jakarta: Rajawali Press, 2010), h. 351.

${ }^{6}$ Beni Ahmad Saebani, Fiqh Munakahat, Bandung: Pustaka Setia, 2009), h. 151. Lihat juga Depertemen Pendidikan dan Kebudayaan, Kamus Besar Bahasa Indonesia, (Jakarta: Balai Pustaka, 1988), h. 639.

${ }^{7}$ Daminikus Rato, Hukum Perkawinan dan Waris Adat di Indonesia, (Yogyakarta: LaksBang PRESSindo, 2015), h. 17.

${ }^{8}$ Pius A. Partanto dan M. Dahlan al-Barry, Kamus Imuah Populer, (Surabaya: ARKOLA, 1947), h. 606.

${ }^{9}$ Beni Ahmad Saebani, Fiqh Munakahat,. 151. 
pula terjadi dengan masa antara. Alasan poligi pada umumnya untuk mendapatkan kerja yang lebih banyak. sebagai pelambang kekuasaan/pengaruh dan kekuasaan lelaki, untuk mendapatkan kekuatan atau gaya hidup sakti dari wanita, pada masyarakat Ghadhu Bhaga poligini bertujuan untuk mengurangi bue duge, perawan tuaterutama wanita rank gae meze (bangsawan besar). ${ }^{10}$

Poliandri adalah istri yang bersuami banyak (lebih dari satu). Berasal dari bahasa Yunani polys atau polus banyak dan ane atau Andros berarti suami (laki-laki). Poliandri adalah pernikahan yang dilakukan oleh seorang perempuan kepada lebih dari seorang lakilaki.Artinya seorang perempuan memiliki suamilebih dariseorang. ${ }^{11}$ Artinya adalah wanita yang digauli oleh banyak laki-laki dalam kurun waktu yang sama. Jika si wanita itu hamil dan melahirkan, ia mengumpulkan laki-laki yang secara rutin menggaulinya.untuk menetapkan siapa ayah si anak tadi, ia menunjuk salah seorang di antara mereka.

Menurut Hamudah Abul'ati, poliandri dapat terjadi akibat beberapa kondisi dari si wanita, seperti rasio seksnya yang berlebihan, tidak mempunyai kecemburuan seks, harta yang berlimpah, mencegah hartanya berpindah ke orang lain. Bentuk lain dari poliandri adalah perempuan yang tidak menolak untuk digauli oleh siapapun dengan imbalan atau tidak. Bentuk inilah yang lazim masih ada sampai masa kini, yang disebut dengan portitusi atau pelacuran. ${ }^{12}$

Monogami adalah perkawinan hanya dengan satu isteri, kalimat ini berasal dari bahasa Yunani monos yang berarti satu dan gamein kawin. ${ }^{13}$ Monogamy adalah pernikahan yang dilakukan oleh seorang laki-laki kepada seorang perempuan. Monogamy adalah asas perkawinan dalam Islam, sehingga suami boleh menikah lebih dari satu asalkan ia berbuat adil, sedangkan keadilan adalah hal yang sulit untuk ditegakkan maka Allah menetapkan, jika

\footnotetext{
${ }^{10}$ Daminikus Rato, Hukum Perkawinan, h. 17.

${ }^{11}$ Beni Ahmad Saebani, Fiqh Munakahat, h. 81.

${ }^{12}$ Rahmat Hakim, Hukum Perkawinan Islām, (Bandung: Pustaka Setia, 2000),

${ }^{13}$ Daminikus Rato, Hukum Perkawinan, h. 17.
} h. $41-42$. 
kamu tidak dapat berbuat adil, maka cukup nikahilah seorang perempuan saja. ${ }^{14}$

Jadi pada dasarnya istilah yang tepat bagi seseorang lakilaki yang memiliki lebih dari seorang dalam waktu bersamaan disebut poliandri bukan poligami. Meskipun demikian, dalam perkataan sehari-hari yang dimaksud dengan poligami itu adalah perkawinan seorang laki-laki dengan lebih dari seorang perempuan dalam waktu yang bersamaan. Poligini tersebut menurut masyarakat adalah poligami. ${ }^{15}$ Khususnya di Indonesia dan Negara-negara yang memakai hukum Islām, maka tanggapan poligini adalah poligami. $^{16}$

\section{Sejarah Poligami}

Poligami adalah masalah-lasalah kemanusiaan yang tua sekali. Hamper seluruh bangsa di dunia, sejak jaman dahulu kala tidak asing dengan poligami. Sebelum Islam, poligami sudah dikenal oleh orang-orang Hindu, Bangsa Israil, Persia, Arab, Romawi, Babilonia, Tunisia, dan lain-lain. ${ }^{17}$ Bangsa Yahudi membolehkan poligami. Nabi Musa tidak melarang, bahkan tidak membatasi sampai berapa isteri seseorang berpoligami itu. Kitab Ulangan 25/5 mewajibkan saudara laki-laki mengawini janda saudaranya yang meninggal tanpa anak, meskipun ia telah beristri. Kitab Ulangan 21/10-17 juga mengatakan kebolehan poligami, seperti Nabi Daud dan Nabi Sulaiman. Nabi Ibrahimpun beristeri dua orang wanita, Nabi Ya'qub beristeri empat orang.

Kitab Talmud, Tafsir Hukum Torat membatasi jumlah isteri dalam perkawinan poligami. Tetapi umat Yahudi pada waktu akhir-akhir kembali menjalankan poligami tanpa batas jumlah isteri. Beberapa ahli Hukum Yahudi ada yang melarang poligami, tetapi ada yang membolehkan dengan syarat apabila isteri pertamanya mandul.

\footnotetext{
${ }^{14}$ Beni Ahmad Saebani, Fiqh Munakahat, h. 81.

${ }^{15}$ MA. Tihami dan Sohari Sahrani, Fikih Munakahat, (Jakarta: Rajawali Press, 2010), h. 351.

${ }^{16}$ Sidi Ghazalba,Menghadapi Soal-Soal Agama, (Jakarta: Pustaka Antara, 1975), h. 25.

${ }^{17}$ MA. Tihami dan Sohari Sahrani, Fikih Munakahat, h. 352.
} 
Ajaran Joroaster melarang Bangsa Persi berpoligami, tetapi membolehkan melarang gundik, sebab sebagai Negara yang banyak berperang, bangsa Persi memerlukan banyak anak laki-laki yang dapat diperbolehkan dari isteri dan gundik-gundik. Akhirnya praktek poligami, praktek poligami terjadi juga dikalangan bangsa Persi. Undang-undang yang melarang poligami atau membatasi banyak isteri tidak ada.

Bangsa Romawi juga mengenal poligami. Raja-raja atau kaisar-kaisar mereka berpoligami. Bangsa Yunani pun mengnal poligami. Raja Silla beristeri 5 orang, Caisar beristeri 4 orang dan Pompius juga beristeri 4 orang isteri. Negara Athena membolehkan poligami tanpa batas jumlah isteri. Dymosin pernah berbangga, karena isterinya terdiri dari tiga tingkatan, yang dua tingkat merupakan isteri resmi dan semi resmi.

Dalam agama Nasrani mula-mula tidak terdapat larangan poligami, sebab nabi-nabi tidak membatalkan syari'ah Nabi Musa (Matius 5/17). Surat Paulus kepada Timotius Pertama 3/2 mengajarkan agar gembala siding (imam jama'at) tidak bercela, menjadi suami seorang isteri saja, menahan diri, sadar, berkelakuan sopan, suka member tumpangan, tahu mengajar orang.

Jelasnya, tidak seorang un dikalangan umat Nasroni kuno yang mengatakan poligami dilarang, banyak diantara mereka yang menjelaskan St. Augustinus menyatakan poligami dibolehkan. Raja Valintinian pada abad IV membuat undang-undang yang membolehkan poligami. Larangan poligami baru diadakan pada masa Raja Yustinian. Bangsa Mesir Kuno juga mengenal poligami, begitu juga bangsa-bangsa India, Babilo, Assyriria dan lainnya.

Bangsa Arab sebelum Islam juga mengenal poligami, ada orang yang beristeri 10 orang, bahkan ada juga beristeri 70 orang. Banyak sahabat-sahabat nabi yang beristeri lebih dari empat orang, setelah ayat al-Qur'an yang membatasi jumlah isteri dalam perkawinan poligami sebanyak-banyaknya empat orang, maka Nabi memerintahkan agar mereka pilih empat orang saja diantara para isterinya yang banyak itu, untuk tetap menjadi isteri, yang lain supaya dicerai. ${ }^{18}$

${ }^{18}$ Ahmad Azhar Basyir, Hukum Perkawinan Islām, (Yogyakarta: Gajah Mada University Press, 1987), h. 34. 
Jauh sebelum Islam lahir, poligami hampir dilakukan oleh semua bangsa, baik Asia, Eropa, Afrika, maupun Amerika. Di Jazirah Arab sendiri, dikenal tidak suka melihat perempuan yang masih kecil, hingga berusaha membunuhnya, mereka berlomba-lomba mendapatkan perempuan dewasa dengan berbagai cara, melalui harta atau kekuasaan.

Dr. August Forel dalam buku Het Sexueele Vraag Stuk, yang dikutip Nadimah Tanjung dalam bukunya Islam dan Perkawinan. Mengatakan poligami ini telah dijalankan oleh bangsa-bangsa sejak jaman primitif, bahkan sampai sekarang. Nahkan bangsa Romawi yang menerapkan peraturan ketat kepada rakyatnya untuk tidak beristeri lebih dari seorang, kaum raja dan bangsawan banyak yang memelihara gundik yang tidak terbatas jumlahnya. Nadimah Tanjung melanjutkan pembahasan masalah ini, menurut sejarah, orang-orang besar dan ternama dari zaman ke zaman sering melakukan poligami. Raja Solomon misalnya, mempunyai tujuh ratus isteri dan berates-ratus gundik. Raja Niger di afrika berinteri ribuan isteri bahkan, rekor fantasis dicapai Raja Uganda yang memiliki tujuh ribu isteri.

Dalam masyarakat tradisional Afrika banyak jumlah isteri termasuk kebanggaan tersendiri, lambang kesuksesan dan status sosial tinggi dan menunjukkan kesejahteraan. Poligami merupakan warisan leluhur orang-orang Afrika, bukan hanya sebagai kewajaran, bahkan hampir sebagai kelembagaan.

Poligami juga banyak dipandang oleh ahli seksiologi seperti Sigmund Freud, Adler, H. Lovie, Jung, Charlotte Burler, Margaret Mead dan lain-lain. Di dunia barat, kebanyakan orang benci dan menentang poligami. Sebagian besar bangsa-bangsa di sana menganggap bahwa poligami adalah hasil dari perbuatan cabul dan oleh karenanya dianggap sebagai perbuatan yang tidak normal. Akan tetapi kenyataan menunjukkan lain, dan inilah yang mengherankan. Di barat, kian merajalela terjadinya praktek-praktek poligami secara luar perkawinan. Hal yang demikian, sejak dulu, bukan rahasia lagi, Karel de Groote, Handrick, Lodewijk, Richealieu, dan Napoleon Bonaparte melakukan poligami, adalah contoh dari kalangan orang-orang eropa yang berpoligami secara illegal itu. Bahkan Pendeta-Pendeta Nasrani yang bersumpah untuk tidak 
kawin seumur hidupnya, tidak malu-malunya juga membiasakan memelihara isteri-isteri gelap dengan izin sederhana dari Uskup atau kepala-kepala gereja mereka.

Melihat realita ini, banyak juga di antara para sarjana Barat, penganjur poligami atau paling tidak orang Barat yang mulai terbuka dan lunak terhadap poligami. Dr. Gustav Le Bon pernah berkata: "pada masa-masa yang akan datang nanti, undang-undang bangsa Eropa akan melegislasikan poligami”. M. Leteurbeau juga pernah berkata: "hingga sampai saat ini, belum juga dapat diyakini bahwa system monogamy ini yang paling baik". ${ }^{19}$

Bangsa Israil melakukan hal yang sama jauh sebelum Nabi Musa as., diutus Allah kesana. Mereka membiasakan pernikahan tersebut tanpa pembatasan. Walaupun ada usaha yang dilakukan para rahib untuk membatasi jumlah pemilikan, ternyata tidak berhasil. Nabi Sulaiman pun menikah dengan banyak isteri, demikian pula pendahulunya, Nabi Daud as., di negara kita banyak pernikahan poligami dilakukan oleh orang-orang besar semacam Ken Arok, Raden Wijaya, Airlangga dan sebagainya.

Kenyataan lain menunjukkan bahwa poligami bukan hanya monopoli Islam. jadi, poligami tidak harus dikaitkan dengan Islam, karena agama-agama lain, baik agama purba maupun agamaagama yang datang belakangan, juga mengenalnya, Prof. Wirjono Prodokoro dalam bukunya Hukum Perkawinan di Indonesia mengutip tulisan Dr.VB. Korn dalam HetAdatrech VaBali, mengatakan, menurut buku hukum Putra Sarana, orang laki-laki hanya dibolehkan beristeri seorang dari kastanya sendiri dan orang masing-masing kasta di bawah kastanya sendiri.

Jadi seorang Brahmana dapat beristeri empat orang, Ksatria 3 orang, dan seterusnya. Akan tetapi peraturan ini hanya berlaku bagi orang-orang penguasa yang sering mempunyai tiga orang, empat atau lima orang isteri. Adapun di antara para Raja tidak jarang ada yang mempunyai 80 sampai 100 orang isteri, bahkan ada yang lebih dari seratus. ${ }^{20}$

${ }^{19}$ MA. Tihami dan Sohari Sahrani, Fikih Munakahat, h. 353.

${ }^{20}$ Rahmat Hakim, Hukum Perkawinan Islām, (Bandung: Pustaka Setia, 2000), h. 120 . 
Tulisan Dr. VB. Korn meryebutkan suatu bantahan bahwa poligami bukan diciptakan oleh Islam, dan bukan hanya dikenal oleh Islam. terbukti bahwa jauh sebelum Islam datang, perkawinan jenis ini telah dilakukan oleh berbagai bangsa dan berbagai agama dan kepercayaan, dihampir seluruh elosok dunia.

Kedatangan Islam hanya sekedar membatasi jumlah wanita yang dapat dimiliki pria dan berpoligami. Bagi laki-laki yang libido seksualnya berlebihan disamping jumlah, Islam juga memberikan aturan-aturan agar tidak terjadinya sewenang-wenang laki-laki terhadap wanita. Jadi pada dasarnya syari'ah Islam adalah dalam upaya mengangkat derajat wanita, seperti apa yang diharapan dalam hakikat perkawinan itu sendiri. ${ }^{21}$

Ternyata poligami telah dikenal oleh bangsa-bangsa dunia jauh sebelum Islam lahir. Islam datang untuk mengatur poligami. al-Qur'an surat al-Nisa' ayat 3 yang membolehkan poligami dalam kontek ayat sebelumnya, merupakan jalan keluar dari kewajiban berbuat adil yang mungkin tidak terlaksana terhadap anak-anak yatim. Dulu orang Arab suka kawin dengan anak-anak perempuan yatim yang diasuh, dengan maksud dapat ikut makan hartanya dan tidak usah memberikan mas kawin. Untuk menghindari jangan sampai orang tersebut tidak adil terhadap anak-anak yatim itu, laki-laki dibolehkan kawin dengan perempuan lain dua, tiga sampai empat orang. Tetapi itupun dengan syarat harus berbuat adil, apabila khawatir tidak akan berbuat adil, supaya kawin dengan seorang isteri saja. perkawinan monogami lebih menjamin seseorang tidak akan berbuat aniaya. ${ }^{22}$

Dalam memandang posisi kaum peremuan pada masa pra Islam, mayoritas intelektual dan sejarawan, terutama dari kalangan Islam, melihatnya sebagai sebuah gambaran kehidupan yang sangat buram dan memprihatinkan, perempuan dipandang sebagai mahluk tak berharga, menjadi bagian dari laki-laki (subordinatif), keberadaannya sering menimbulkan masalah, tidak memiliki independensi diri, hak-haknya boleh ditindas dan dirampas, tubuhnya dapat dijual belikan atau diwariskan, dan

\footnotetext{
${ }^{21}$ Ibid.,, h. 119-221.

${ }^{22}$ Ahmad Azhar Basyir, Hukum Perkawinan, h. 34.
} 
diletakkan dalam posisi marginal, serta pandangan-pandangan yang menyedihkan lainnya. ${ }^{23}$

Dalam pembicaraan tentang sejarah perempuan dari masa pra Islam sampai masa kedatangan Islam, melewati fase sejarah yang oleh kalangan intelektual muslim disebut dengan zaman Jahiliyah. Istilah jahiliyah ini sangat popular dan identik dengan kebodohan.

Kata jahiliyah berasal dari kata jahlun, yang artinya bodoh. Jahiliyah adalah bangsa yang bodoh. Menurut Mu'jam al-Wasith, kata jahiliyah berarti dua pengertian, yaitu:

1. Kebodohan dan kesesatan bangsa Arab sebelum datangnya Islam. Semua kebodohan dan kedzaliman menurut umat Islam adalah jahiliyah.

2. Masa kebodohan antara dua rasul. Tradisi (masa kekosongan) di antara dua rasul. Pada masa ini terdapat masa tradisi, masyarakat pada waktu itu sudah lepas dari ajaran kenabian Isa as., dan belum menerima kenabian Muhammad saw. Dengan demikian, tidak semua masa diklaim sebagai jahiliyah. Pada masa inilah terjadi penyimpangan-penyimpangan ajaran Isa as., oleh para pengikut yang menginkari adanya nabi setelah Isa as.

Terlepas dari pengaruh jahiliyah terhadap Islam, yang jelas ada perbedaan terhadap perempuan antara jaman jahiliyah dengan setelah datangnya Islam dan perlakuan jahiliyah terhadap perlakuan perempuan. Syafiq Hasyim mendefinisikan beberapa cirri-ciri jahiliyah yang ditolak oleh Islam. tardisi dan budaya apapun, kalau sesuai dengan ciri ini, bisa dianggap sebagai jahiliyah, walaupun tidak terjadi pada masa jahiliyah terdahulu. Yaitu:

1. Perempuan adalahyang tidakdikenaloleh undang-undang. Perempuan bukan sebagai mahluk hukum sehingga tidak patut masuk dalam peraturan perundangan. Apabila masuk, maka dia berada pada posisi yang tidak menguntungkan.

2. Perempuan pada masa ini dipersepsikan sebagai harta benda. Sebagai harta, apabila sudah kita miliki, kita

${ }^{23}$ Syafiq Hasyim, Hal-Hal yang Tak Terpikirkan tentang Isu-Isu Perempuan dalam Islām, (Bandung: Penerbit Mizan, 2001), h. 18-19. 
berhak melakukan apa saja sesuai dengan keinginan kita. Apakah kita jual lagi, atau kita pakai sendiri. Jadi pada masa ini seorang suami sudah biasa menjual isteri ada orang lain.

3. Menurut tradisi jahiliyah, perempuan tidak memiliki hak talak (cerai). Oleh karena itu, apabila diberlakukan apa saja oleh suaminya, isteri harus dengan sabar menerimanya, karena isteri dalam posisi yang buruk seperti ini, ia tidak bisa melepaskan ikatan perkawinan dari suaminya. Posisi yang terus-menerus dalam kondisi yang ketergantungan.

4. Perempuan tidak memiliki hak waris, tetapi malah diwariskan sebagaimana tanah, hewan dan benda kekayaan yang lain. Ketiadaan hak untuk mewarisi ini menunjukkan bahwa tradisi pra Islam menghabisi kesempatan perempuan untuk hidup secara mandiri dan maju.

5. Perempuan tidak memiliki hak memelihara anaknya. Anak bagi masyarakat pra Islam adalah milik laki-laki, hal ini sesuai dengan garis keturunan yang bersifat patrilinier.

6. Perempuan tidak memiliki hak membelanjakan hartanya. Pada pandangan masyarakat jahiliyah, perempuan sendiri adalah harta. Bagaimana dapat membelanjakan harta, sedangkan ia adalah bagian hari harta.

7. Penguburan bayi perempuan hidup-hidup. Ini merupakan tragedi besar sejarah perempuan pra-Islam. perempuan ini adalah hal yang secara langsung direkam oleh al- Qur'an. ${ }^{24}$

Jika kita lihat kenyataan di atas, tradisi tersebut sangat berlawanan dengan ajaran Islam, bahkan zaman jahiliyah tidaklah mewujudkan sebuah toleransi kepada perempuan dalam hal, memberikan hak-hak dan dalam memberlakukan mereka di derajat yang mulia.

Islam adalah agama yang ditujukn untuk semua manusia tanpa membedakan jenis kelamin, suku, ras, kelompok dan bahkan juga agama. Ruh Islam terletak pada etikanya yang membebaskan,

${ }^{24}$ Ibid., h. 28-30. 
seperti tercermin dalam ajaran dasar Islam, yaitu tauhid. Tauhid adalah sesuatu pengakuan yang tulus terhadap kesamaan dan kesatuan manusia. Semua manusia sama, dan berasal dari sumber satu, taitu Tuhan. Yang membedakan diantara manusia adalah prestasi dan kekuatan takwanya, dan berbicara taqwa hanyalah Allah yang tahu secara otoritas. Ajaran tauhid inilah yang harus dijadikan landasan dalam menempatkan posisi perempuan dalam hukum Islam. ${ }^{25}$

Secara ideal, Islam memiliki pandangan kesetaraan yang cukup tegas mengenai hubungan dan tugas antara laki-laki dan perempuan. Pandangan kesetaraan itu dapat dilihat dalam sejumlah ayat al-Qur'an, misalnya tentang penyebutan asal kejadian manusia, baik laki-laki maupun perempuan. ${ }^{26}$ Disana disebutkan bahwa keduanya berasal atau diciptakan dari jenis yang sama, sehingga mereka memiliki hak yang sama pula. Dalam al-Qur'an surat alNisâa ${ }^{27}$ Allah SWT., menegaskan dalam surat al-Nisâ' ayat $1{ }^{28}$

Perbedaan fungsi biologis antara laki-laki dan perempuan tidak berarti membedakan status dan kedudukan yang setara antara keduanya. Mengenai hal yang terakhir diisyaratkan dalam al-Qur'an bahwa Allah telah memuliakan anak Adam. Yang dimaksud dengan anak Adam disini adalah manusia laki-laki dan perempuan. ${ }^{29}$

${ }^{25}$ Ratna Bantara Munti, Posisi Perempuan dalam Hukum Islam di Indonesia, (Yogyakarta: LKiS, 2005), h. ix.

${ }^{26}$ Asgar Ali Engineer, Pembebasan Perempuan, (Yogyakarta: LKiS, 2007), h. 237-238.

${ }^{27}$ Surat al-Nisâ, yang terdiri dari 176 ayat adalah surat madaniyyah yang terpanjang sesudah surat al-Baqarah yang berarti perempuan-perempuan, boleh jadi karena ayat yang pertama kali telah disebut al-Nisâ, dan boleh jadi karena dalam surat ini banyak dibicarakan hal-hal yang berhubungan dengan perempuan, dan merupakan hal yang paling banyak menceritakan hal itu dibandingkan surat-surat yang lain, sehingga sering disebut al-nisâ al-kubrâ. Penamaan ini untuk membedakan dengan surat lain yang juga memaparkan tentang perempuan dalam banyak ayatnya, yaitu surat al-thalâq yang dinamakan al-nisâ al sughrâ.dalam surat ini disebutkan banyak bersangkutan dengan peraturan, khusunya mengatur hakhak laki-laki dan perempuan. Nur Jannah Ismail, Perempuan dalam Pasungan Bias LakiLaki dalam Penafsiran, (Yogyakarta: LKiS, 1999), h. 27.

${ }^{28}$ Kementerian Agama RI., Undang-undang Perkawinan Tahun 1974, (Bandung: Fermana, 2007) h. 61.

${ }^{29} Y$ Yunahar Ilyas, Feminisme dalam Kajian Tafsir Al-Qur'ān Klasik dan Kontemporer, (Yokyakarta: Pustaka Pelajar, 1997), h. 121. 


\section{Poligami dalam Islam}

Menurut Mahmud Syaltut, Hukum poligami adalah mubah, selama tidak dikhawatirkan terjadinya penganiayaan terhadap isteri. Namun jika dikhawatirkan penganiayaan dan itu menimbulkan dosa maka sebaiknya beristri satu saja. maka pada dasarnya poligami adalah masalah keadilan, dan tidak terjadinya penganiayaan terhadap isteri. ${ }^{30}$

Islam adalah agama yang fitrah, agama yang sejalan dengan tuntunan watak, dan sifat pembawaan kejadian manusia. Oleh karena itu, Islam memperhatiakan kenyataan-kenyataan manusiawi, kemudian mengaturnya agar sesuai dengan nilai-nilai keutamaan. Pengaruhiklim membawakan perbedaan-perbedaandalamkenyataan hidup manusia. Tiap-tiap individu mempunyai pembawaan yang mungkin berbeda dengan individu lain. Keadaan sosial dalam suatu masyarakat pada masa tertentu mengalami roblem-problem yang minta pemecahan. ${ }^{31}$

Islam membolehkan poligami sampai empat orang isteri dengan syarat berlaku adil kepada mereka. Yaitu adil dalam melayani isteri, seperti urusan nafkah, tempat tinggal, pakaian, giliran dan hal-hal yang bersifat lahiriyyah. Jika tidak dapat berbuat adil, maka hanya cukup satu isteri saja (monogami). Hal ini berdasarkan firman Allah swt., surat al-Nisa' ayat 3:

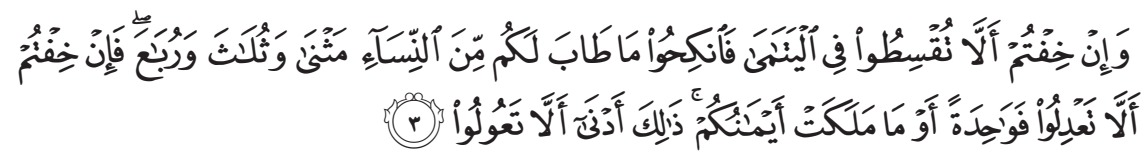

"Dan jika kamu takut tidak akan dapat Berlaku adil terhadap (hakhak) perempuan yang yatim (bilamana kamu mengawininya), Maka kawinilah wanita-wanita (lain) yang kamu senangi : dua, tiga atau empat. kemudian jika kamu takut tidak akan dapat Berlaku adil, ${ }^{32}$ Maka (kawinilah) seorang saja, ${ }^{33}$ atau budak-budak yang kamu miliki.

${ }^{30}$ Mahmud Syaltut, Islam Akidah dan Syari'ah, Cet. Ke-III, (Mesir: Dar alQolam, 1966), h. 269.

${ }^{31}$ Ahmad Azhar Basyir, Hukum Perkawinan Islām, h. 35.

32 Berlaku adil ialah perlakuan yang adil dalam meladeni isteri seperti pakaian, tempat, giliran dan lain-lain yang bersifat lahiriyah.

${ }^{33}$ Islam memperbolehkan poligami dengan syarat-syarat tertentu. sebelum turun ayat ini poligami sudah ada, dan pernah pula dijalankan oleh Para Nabi sebelum Nabi Muhammad s.a.w. ayat ini membatasi poligami sampai empat orang saja. 
yang demikian itu adalah lebih dekat kepada tidak berbuat aniaya. (QS. al-Nisa':3).

Ayat ini turun (asbabun nuzulnya) berkaitan dengan sikap Ghillan (seorang suami yang ingin menikahi anak-anak yatim yang cantik dan kaya yang berada di bawah perwaliannya, tanpa mas kawin/mahar. Menurut kebiasaan yang berlaku pada masyarakat Arab jahiliyah terdahulu, para wali anak yatim mepeardukkan hartanya dengan harta anak yatim yang dipelihara. Kalau kebetulan anak perempuan itu cantik dan banyak hartanya, si wali menikahinya tanpa mahar, atau dengan maharyang sedikit. Tapi jika anak tersebut tidak cantik, si wali enggan menikakkannya dengan orang lain, agar anak harta yatim tidak jatuh ketangan orang lain tersebut. Itulah sebabbya ayat tersebut menyebutkan bahwa jika wali tersebut khawatir tidak berbuat adil kepada anak yatim itu, maka para wali itu dianjurkan untuk menikahi perempuan lain saja, boleh dua, tiga atau empat. ${ }^{34}$

Muhammad Ali al-Shabuni dalam Kitabnya Tafsir ayat alAhkam, membedakan status hukum poligami, sebagai berikut; (fankihuu maa thaaba lakum) hukumnya wajib (boleh; tidak mengikat). Ulama jumhur sepakat bahwa amr dalam ayat tersebut ibahah seperti makana amr dalam firman Allah lainnya (wa kuluu wasyrabuu) dan ayat (kuluu min thayyibaatii maa razaqnaakum), sementara ulama' Dhahiriyah berpendapat nikah tersebut wajib, kami berpegang kepada Dhahir ayat karena sesungguhnya amr itu wajib.

Lebih lanjut ia menjelaskan ayat 4 surat al-Nisa': (fankihuu maa thaaba lakum min al-nisaa'i matsa wa tsulaasa wa ruba'..) makna kawinilah wanita-wanita (lain) yang kamu senangi, kata ini adalah perintah yang boleh dilakukun oleh seorang laki-laki menikahi wanita yang disenangi. Kata maa diatas sama artinya dengan kata man. ${ }^{35}$

Menurut Ali al-Sayis, dijelaskan bahwa (matsa wa tsulaasa wa rubaa'a) merupakan hal dari kata thaba yang merupakan kalimat hitungan yang menunjukkan jumlah yang disebut itu. Misalnya lafadz matsa menunjukkan kepada dua-dua, wa tsulaasa

${ }^{34}$ M. Anshary MK, Hukum Perkawinan di Indonesia, (Jakarta: Pustaka Pelajar, 2010), h. 87.

${ }^{35}$ Muhammad Ali al-Shabuni, Tafsir Ayat al-Ahkam, jilid ke-1, (Bairut: Dar al-Fikr, tt.), h. 426. 
menunjukkan kepada tiga-tiga, wa rubaa'a menunjukkan kepada empat-empat. Sedangkan penafsiran huruf waw dalam kata wa tsulasa wa rubaa'a menempati huruf au yang berarti atau. Hal itu berfungsi menambah yaitu dan. Begitu juga bilangan matsa, tsulaasa, rubaa'a yang dimaksud disini artinya dua, tiga, empat. Dengan demikian, batas maksimal oligami adalah empat orang.

Pengertian tersebut diperkuat oleh runtutan kata dengan ayat tersebut. Hal tersebut terbukti ada kata nilk al-yamin secara mutlak. Pengertian umum yang diperoleh dari lafadz maa thaaba lakum sudah dikhususkan oleh dua hal. yaitu:

1. Mukhassis yang bersifat maknawi, khitab pada fa al-ankihuu maa thaaba lakum adalah orang Islam. sedangkan orang Islam tidak suka dengan hal-hal yang dilarang dan mengawini wanita lebih dari empat orang adalah sesuatu yang tidak halal.

2. Mukhashis yang bersifat lafdzi, adanya keterangan pada kata maa thaabalakum minal-nisa'i berupa bilangan matsna, tsulasa wa rubaa'a. ini merupakan kata tunggal yang dipakai untuk menyebut bilangan yang berulang-ulang. Maka artinya kawinilah olehmu wanita-wanita yang halal bagimu, dua-dua, tiga-tiga atau empat-empat, dan kamu tidak boleh mengambil isteri lebih dari empat.

Jadi maksud dari ayat tersebut adalah larangan menikah lebih dari empat dengan tujuan menjaga agar harta anak yatim dipergunakan oleh wali mereka. Diriwayatkan bahwa seorang pria qurays memiliki 10 orang wanita, jika dia mengalami kesulitan ekonomi, dia mempergunakan harta anak yatim yang dalam perwaliannya atau dinikahinya. Hal itu dilarang dan dikatakan kepada mereka, jika kamu khawatir akan harta anak yatim dalam perwalianmu dipergunakan olehmu sehingga kamu berlaku tidak adil maka memenuhi kewajiban kalian atas harta itu karena pengertian member makan isterimu merupakan kewajibanmu, maka janganlah menikahi perempuan lebih dari empat, jika empat tersebut masih membuatmu tidak adil harta anak yatim itu, maka cukup satu saja jika atau kawinilah budak-budak yang kamu miliki. ${ }^{36}$

${ }^{36}$ Dedi Supriyadi dan Mustofa, Perbandingan Hukum Perkawinan di Dunia 
Menurut Quraish Shihab, "Jika kami takut tidak akan berbuat adil terhadap perempuan yatim dan kamu percaya diri akan berlaku adil terhadap perempuan-perempuan selain yang yatim itu, maka kawinilah apa yang kamu sayangi sesuai selera kamu dan halal bagi perempuan-perempuan yang lain itu. Kalau perlu kamu dapat menggabung dua, tiga, empat, tetapi jangan lebih, kalau kamu takut tidak akan dapat berlaku adil dalam hal harta dan perlakuan lahiriyah, bukan dalam hal cinta bila menghimpun lebih dari seorang isteri, maka kawini seorang saja, atau kawinilah budak-budak yang kamu miliki. Yang demikian itu, yakni menikahi selain anak yatim yang mengakibatkan ketidak adilan, dan mencukupkan satu orang isteri adalah lebih dekat tidak berbuat aniaya, yakni lebih mengantarkan kamu kepada keadilan atau kepada tidak memiliki banyak anak yang harus kamu tanggung biaya hidup mereka. ${ }^{37}$

Al-Juzairi dalam Kitabnya al-Fiqh 'ala Madzahid al-Arba'ah, mengungkapkan tentang status poligami, pokok poligami pada dasarnya terletak pada persoalan "adil". Jika takut mengatakan adil, maka cukup menikah dengan satu isteri, sebaliknya jika mampu menegakkan adil, maka dibolehkan beristeri lebih dari satu. Oleh karena itu, syarat adil adalah wajib. Meskipun dalam hal tertentu,menegakkan adil dalam hal beristeri lebih dari satu bisa hukumnya mandub (sunnah). ${ }^{38}$

Berkait dengan masalah ini, Rasyid Ridha mengatakan, sebagaimana yang dikutip oleh Masyfuk Zuhdi, bahwa Islam memandang poligami lebih banyak resiko/mudharat daripada manfaat karena manusia itu menurut fitrahnya (hukan nature) memunyai watak cemburu, iri hati dan suka mengeluh. Watakwatak tersebut akan mudah timbul dengan kadar tinggi, jika hidup dalam kehidupan poligamis. Dengan demikian, poligami itu bisa membawa sumber konflik dalam kehidupan keluarga, baik konflik antara suami dengan isteri-isteri maupun konflik antara isteriisteri terhadap anak-anaknya masing-masing., oleh karena itu, usul

Islām, (Bandung: Pustaka Al-Fikriis, 2009), h. 84-85.

${ }^{37}$ M. Quraish Shihab, Tafsir al-Misbah, cet. Ke-I, jilid ke-II, (Ciputat: Lentera Hati, 2000), h. 321-322.

${ }^{38}$ Dedi Supriyadi dan Mustofa, Perbandingan Hukum Perkawinan di Dunia Islām, h. 82-83. 
hukum perkawinan dalam Islam adalah monogami, sebab dengan monogamy akan memudahkan menetralisasi sifat/watak cemburu, iri hati dan suka mengeluh dalam kehidupan keluarga yang harmonis. Berbeda dengan kehidupan keluarga yang poligamis, orang akan mudah peka dan terangsang timbulnya perasaan cemburu, iri hati/dengki, dan suka mengeluh dalam kadar tinggi, sehingga dapat mengganggu ketenangan keluarga dan dapat pula membahayakan keutuhan keluarga.karena itu, poligami hanya diperbolehkan bila dalam keadaan darurat, misalnya isteri ternyata mandul, sebab menurut Islam, anak itu merupakan salah satu dari tiga human investment yang sangat berguna bagi manusia setelah ia meninggal dunia, yakni bahwa amalnya tidak tertutup berkah adanya keturunan yang shalih yang selalu berdo'a untuknya. Maka dalam keadaan isteri mandul dan sumi tidak mandul, berdasarkan keterangan medis hasil laboratories, suami diijinkan berpoligami dengan syarat ia benar-benar mampu menutupi nafkah untuk semua keluarga dan harus bersikap adil dalam pemberian nafkah lahir dan giliran waktu tinggalnya. ${ }^{39}$

Islam membolehkan poligami dengan jumlah wanita yang terbatas dan tidak mengharuskan umatnya menjalankan monogamy mutlak dengan pengertian orang laki-laki hanya boleh beristeri seorang wanita dalam keadaan dan situasi apapun dan tidak pandang bulu apakah laki-laki-itu kaya atau miskin, hiposeks atau hiperseks, adil atau tidak adil secara lahiriyah. Islam pada dasarnya menganut system monogamy dengan memberikan kelonggaran dibolehkannya poligami terbatas. Pada prinsipnya, seorang laki-laki hanya memiliki seorang isteri, dan sebaliknya seorang isteri hanya memiliki seorang suami. Tetapi Islam tidak menutup kecenderungan laki-laki untuk beristeri banyak sebagaimana yang sudah berjalan dahulu kala. Islam tidak menutup rapat kemungkinan adanya laki-laki tertentu untuk berpoligami, tetapi tidak semua laki-laki harus berbuat demikian karena tidak semua memuanyai kemampuan untuk berpoligami, poligami dalam Islah hanya dibatasi dengan syarat-syarat tertentu, baik jumlah maksimal maupun persyaratan lain, seperti:

1. Jumlah isteri yang boleh dipoligami paling banyak empat orang wanita. Bila di antara isteri ada yang meninggal

${ }^{39}$ Abdul Rahman Ghazali, Fikh Munakahat, (Jakarta: Kencana, 2003), 130. 
dunia atau diceraikan, suami dapat mencari ganti yang lain asalkan jumlahnya empat orang dalam waktu yang bersamaan.

2. Laki-laki itu dapat berbuat adil bagi isteri-isteri dan anakanaknya, yang menyangkut masalah-masalah lahiriah seperti pembagian waktu dalam pembagian nafkah, dan hal-hal yang menyangkut kepentingan lahir. Sedangkan masalah batin, tentu saja, selamanya manusia tidak dapat berbuat adil selamanya.

Islam membolehkan laki-laki berpoligami sebagai alternatif atau jalan keluar untuk mengatasi penyaluran kebutuhan seks lakilaki atau sebab-sebab lain yang mengganggu ketenangan batinnya agar tidak sampai jatuh kelembah perzinaan maupun pelajaran yangjelas-jelas diharamkan agama. Oleh karena itu, tujuan poligami adalah menghindari agar suami tidak terjerumus kejurang maksiat yang dilarang Islam dengan mencari jalan yang halal, yaitu boleh beristeri lagi (poligami) dengan syarat bisa berbuat adil. ${ }^{40}$

Menurut Zamaksyari, poligami menurut syari'ah Islam adalah merupakan rukhsah (kelonggaran) ketika darurat, sama halnya rukhsah bagi musafir dan orang sakit yang dibolehkan buka puasa pada bulan ramadhan ketika dalam perjalanan. ${ }^{41}$

Namun demikian, ada beberapa alasan dibolehkannya poligami, sebagaimana pendapat Syaikh Shahih bin Fauzan bin Abdullah, seorang wanita yang menikah dengan laki-laki yang bertanggungjawab penuh, menjamin kehidupannya, memberikan perlindungan, dan bisa mendatangkan banyak keturunan, sekalipun ia sebagai isteri keempat, masih lebih baik daripada ia tetap lajang. Sebab, dia tidak akan merasakan keindahan pernikahan, sedangkan disisi lain ia akan menjadi sasaran fitnah. ${ }^{42}$

Bahkan Muhammad Abduh mengatakan bahwa haram berpoligami, bagi seseorang yang khawatir tidak bisa berbuat adil. ${ }^{43}$

40 Abdul Rahman Ghazali, Fikh Munakahat, (Jakarta: Kencana, 2003), 357- 358.

41 Muhammad al-Bahy, al-Islam wa Tijah al-Mar'ah al-Muashirah, (Mesir: Maktabah Wahbah, 1978), h. 42.

${ }^{42}$ Syaikh Hasan Ayyub, Fikih Keluarga, (Jakarta: Pustaka Al-Kautsar, 2001), h. 174.

${ }^{43}$ Muhammad al-Bahy, Op.Cit., h. 45. 
Karena pada dasarnya, poligami tidaklam mendatangkan manfaat, bahkan poligami hanyalah mencari kesenangan. ${ }^{44}$

Ibnu Abd al-Salam mengemukakan; "Dulu pada zaman Syari'ah Musa as., perempuan dinikahi tanpa batas untuk kemaslahatan laki-laki. Pada zaman Syari'ah Isa as., tidak dibolehkan dinikahi kecuali satu untuk kemaslahatan perempuan. Pada masa Syari'ah Nabi kita, kedua maslahah tersebut dipelihara. Adapun hikmah di balik itu adalah sebagai berikut. Pada masa Musa as., kemaslahatan laki-laki didahulukan karena Rezim Fir'an telah membunuh anak laki-laki mereka dan membiarkan anak perempuan, pantaslah pada masa Musa as., kemaslahatan laki-laki dimenangkan karena sedikitnyalaki-laki dan banyaknya perempuan. Pada masa Isa as., dimenangkan kemaslahatan perempuan, karena Isa diciptakan tanpa ayah (bil abin), maka pantaslah jika syari'ah Isa as., memenangkan kemaslahatan. Adapun syari'ah Umat Islām, hikmah dibolehkannya nikah emat adalah karena setiap orang memiliki karakter yang empat dan yang dimaksud dengan nikah adalah kasih dan saling saying, dan hal ini bisa hilang kalau lebih dari empat unsur.

Jadi, pada dasarnya syari'ah Islam adalah membatasi empat isteri dalam pernikahan (poligami) memberikan maslahat pada umatnya, yaitu mengoreksi umat-umat sebelumnya (syari'at umat sebelumnya). Tampaknya al-Badjuri ingin menunjukkan keadilan syari'ah Islam dan toleransi Islam terhadap perempuan dengan cara memperhatikan hak-hak mereka, yaitu syari'ah yang menyinergikan gagasan-gagasan kemaslahatan umum dalam satu wadah Islam, dan mengoreksi syari'ah-syari'ah pra-Islam yang tidak membawa kemaslahatan.

Pendapat tersebut juga dijadikan sebagai upaya rasionalisasi Islam terhadap poligami. Namun, secara historis, apa yang dikemukakan tidak didukung bukti yang kuat. Pendapat ini bahkan berlawanan dengan sumber lain yang menunjukkan bahwa poligami merupakan lompatan kebijakan sekaligus sebagai koreksi

${ }^{44}$ 'Abd al-Nasr Taufiq al-'Athar, Ta'adud al-Zaujah nin Nawahi al-Diniyyah wa al-Ijtimaiyyah wa al-Qanuniyyah, (Qohirah: al-Syarikah al-Mishriyyah li al-Thalabah wa al-Nasyr, 1972), h. 21. 
Islam terhadap syari'ah sebelumnya, yang membolehkan laki-laki mengawini perempuan dengan seenaknya tanpa batas.

Pada masa Nabi ada salah seorang sahabat bernama Ghilan al-Tsaqafi. Ia mempunyai sepuluh orang isteri. Kemudian hal ini dilaporkan kepada Nabi saw., dan Nabi saw., menyuruhnya untuk mengambil empat diantara sepuluh isteri itu. Hal ini membuktikan bahwa poligami merupakan respon sosiologis dan antropoligis alQur'an terhadap masyarakat saat itu. ${ }^{45}$

Suami wajib berbuat adil terhadap isteri-isterinya dalam urusan pangan, pakaian, tempat tinggal, giliran pada masing-masing isteri, dan lainnya yang bersifat kebendaan, tanpa membedakan antara isteri yang kaya dengan isteri yang miskin, yang berasal dari keturunan tinggi dengan yang dari keturunan bawah, jika masingmasing isteri memiliki jumlah anak yang berbeda, atau jumlahnya sama tapi biaya pendidikannya berbeda, tentu saja hal ini harus menjadi pertimbangan dalam memberikan keadilan.

Jika suami khawatir berbuat dzalim dan tidak mampu memenuhi hak mereka maka is haram melakukan poligami. Bila ia hanya mampu memberikan keadilan kepada tiga perempuan, maka ia haram menikahi isteri keempatnya. Jika ia hanya mampu memenuhi kewajiban kepada dua orang, maka ia haram menikahi yang ketiga, dan begitu seterusnya.

Berkenaan dengan keadilan suami terhadap isteri, Nabi saw., bersabda:

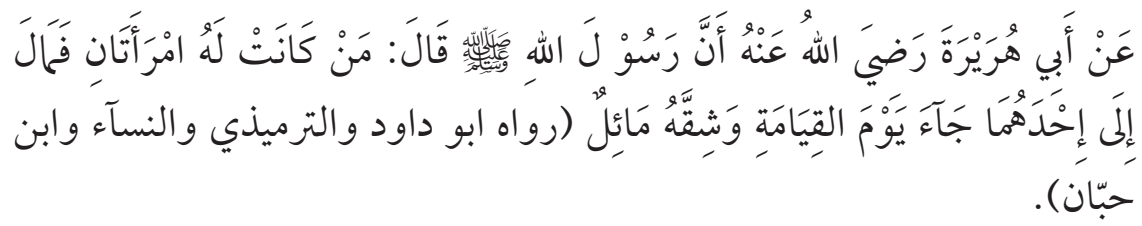

Dari Abu Hurairan ra., sesungguhnya Nabi saw., bersabda: "Barang siapa yang mempunyai dua orang isteri, lalu memberatkan kepada salah satunya maka is datang pada hari Kiamat dengan bahunay miring". (HR. Abu Daud, al-Tirmidzy, Nasa'i dan Ibnu Hibban).

Mengenai adil terhadap isteri-isteri dalam masalah cinta dan kasih sayang, Abu Bakar bin Araby, bahwa hal ini merupakan hal yang berada diluar kemampuan manusia, sebab cinta itu adanya

${ }^{45}$ Syafiq Hasyim, Hal-Hal yang Tak Terpikirkan tentang Isu-Isu Perempuan dalam Islām, (Yogyakarta: LKiS, 2001), h. 160. 
dalam genggaman Allah swt., yang mampu membolak-balik sesuai kehendak-Nya. Begitu juga hubungan seksual, terkadang suami bergairah pada isteri yang satunya. ${ }^{46}$

\section{E. Kesimpulan}

Secara historis poligami sudah dilakukan oleh umat-umat sebelum datangnya Islam. mereka bebas melakukan poligami dengan banyak perempuan. Kedatangan hukum Islam dalam hal poligami lebih bersifat mengatur, membentengi dan membatasi jumlah isteri yaitu maksimal empat, dengan syarat harus adil. Hal ini dilakukan lebih kepada perlindungan kepada perempuan. Ini adalah suatu bentuk toleransi agama Islam yang mengoreksi ajaran-ajaran nenek moyang sebelum datangnya Islam (masa jahiliyah) antara syari'ah Isa as., menjelang datangnya syari'ah Muhammad saw. []

\section{Daftar Pustaka}

Abdurrahman, Kompilasi Hukum Islam, Jakarta: Akademika Pressindo, 2007.

al-'Athar, 'Abd al-Nasr Taufiq, Ta'adud al-Zaujah nin Nawahi al-Diniyyah wa al-Ijtimaiyyah wa al-Qanuniyyah, (Qohirah: al-Syarikah alMishriyyah li al-Thalabah wa al-Nasyr, 1972.

al-Bahy, Muhammad, al-Islam wa Tijah al-Mar'ah al-Muashirah, Mesir: Maktabah Wahbah, 1978.

al-Shabuni, Muhammad Ali, Tafsir Ayat al-Ahkam, jilid ke-1, Bairut: Dar al-Fikr, tt.

Ayyub, Syaikh Hasan, Fikih Keluarga, Jakarta: Pustaka AlKautsar, 2001.

Basyir, Ahmad Azhar, Hukum Perkawinan Islam, Yogyakarta: Gajah Mada University Press, 1987.

Depertemen Pendidikan dan Kebudayaan, Kamus Besar Bahasa Indonesia, Jakarta: Balai Pustaka, 1988.

Engineer, Asgar Ali, Pembebasan Perempuan, Yogyakarta: LKiS, 2007. Ghazali, Abdul Rahman, Fikh Munakahat, Jakarta: Kencana, 2003.

${ }^{46}$ Abdul Rahman Ghazali, Fiqh Munakahat, h.132-133. 
Hakim, Rahmat, Hukum Perkawinan Islam, Bandung: Pustaka Setia, 2000.

Hasyim, Syafiq, Hal-Hal yang Tak Terpikirkan tentang Isu-Isu Keperempuanan dalam Islam, Bandung: IKAPI, 2001.

Ilyas, Yunahar, Feminisme dalam Kajian Tafsir al-Qur'ān Klasik dan Kontemporer, Yokyakarta: Pustaka Pelajar, 1997.

Ismail, Nur Jannah, Perempuan dalam Pasungan Bias Laki-Laki dalam Penafsiran, Yogyakarta: LKiS, 1999.

Mahkamah Agung RI, 2008, Buku II Edisi 2007, tentang Pedoman Teknis administrasi dan Teknis Pengadilan Agama

MK., M. Anshary, Hukum Perkawinan di Indonesia, Jakarta: Pustaka Pelajar, 2010.

Munti, Ratna Bantara, Posisi Perempuan dalam Hukum Islam di Indonesia, Yogyakarta: LKiS, 2005.

Mustaqim, Abdul, Paradigma Tafsir Feminis, Yogyakarta: Logung Pustaka, 2008.

Partanto, Pius A., dan al-Barry, M. Dahlan, Kamus Ilmuah Populer, Surabaya: ARKOLA, 1947.

Rato, Daminikus, Hukum Perkawinan dan Waris Adat di Indonesia, Yogyakarta: LaksBang PRESSindo, 2015

Saebani, Beni Ahmad, Fiqh Munakahat, Bandung: Pustaka Setia, 2009.

Shihab, M. Quraish, Tafsir al-Misbah, cet. Ke-I, jilid ke-II, Ciputat: Lentera Hati, 2000.

Supriyadi, Dedi, dan Mustofa, Perbandingan Hukum Perkawinan di Dunia Islām, Bandung: Pustaka Al-Fikriis, 2009.

Syaltut, Mahmud, Islam Akidah dan Syari'ah, Cet. Ke-III, Mesir: Dar al-Qolam, 1966.

Tihami, MA., dan Sahrani, Sohari, Fikih Munakahat, Jakarta: Rajawali Press, 2010.

Kementerian Agama RI, Undang-Undang Perkawinan Tahun 1974, Bandung: Fermana, 2007.

Yanggo, Huzaimah Tahido, Fikih Perempuan Kontemporer, Bogor: Ghalia Indonesia, 2010. 